\title{
Ewa Cuber-Strutyńska
}

\section{Witold Pilecki. Konfrontacja z legendą o „ochotniku do Auschwitz”}

Śmierć miała wiele okazji, by przedwcześnie zakończyć życie Witolda Pileckiego, uczestnika walk o niepodległość podczas wojny z bolszewikami oraz drugiej wojny światowej. Pomimo podejmowanego ryzyka uniknął jej podczas walk na froncie, pobytu w KL Auschwitz oraz uczestnicząc w powstaniu warszawskim. Za tragiczny paradoks należy uznać fakt, że dosięgła go w niepodległej z pozoru Polsce, i to za sprawą m.in. dawnych towarzyszy broni. Pilecki stał się ofiarą reżimu komunistycznego, który zadał mu podwójną śmierć. Pierwszą - strzałem w tył głowy - zadano mu 25 maja 1948 r., drugą - symboliczną - zadano jego pamięci, poddając ją kilkudziesięcioletniej cenzurze.

Uwolnienie pamięci o Pileckim oraz jego rehabilitacja nastąpiły dopiero po upadku reżimu, z którego rąk zginął. Począwszy od lat dziewięćdziesiątych, powstają kolejne biografie Pileckiego, dzięki którym powrócił on na karty historii Polski i dołączył do panteonu Polaków zasłużonych dla ojczyzny. Ponadto od kilku lat można obserwować niesłabnące, a wręcz wzrastające zainteresowanie Pileckim. Jego postać popularyzują już nie tylko publikacje naukowe (o dość wąskim przecież odbiorze), lecz przede wszystkim różnego rodzaju działania instytucji państwowych, organizacji pozarządowych, środowisk prawicowych, a także kibice klubów piłkarskich ${ }^{1}$. Wśród coraz liczniejszych inicjatyw uhonorowania Pileckiego powstał nawet pomysł podjęcia starań o jego beatyfikację ${ }^{2}$.

\footnotetext{
${ }^{1}$ Podczas rozegranego 3 V 2012 r. meczu Śląska Wrocław z Jagiellonią Białystok kibice Śląska w hołdzie dla Pileckiego przygotowali oprawę meczu przedstawiającą m.in. jego portret podpisany „Ochotnik do Auschwitz”, wraz z cytatem: „bo Oświęcim przy nich to była igraszka”. W 2013 r. z okazji 65. rocznicy śmierci Pileckiego podobną oprawę nadali meczom kibice Zawiszy Bydgoszcz i Widzewa Łódź, a kibice Legii Warszawa zorganizowali w Milanówku wiec upamiętniający rotmistrza. Tym samym postać Pileckiego połączyła pełne antagonizmów środowisko kibiców i rotmistrz stał się ich idolem.

${ }^{2}$ Autorem pomysłu oraz listów skierowanych do papieży Benedykta XVI (w 2008 r.) i Franciszka (w 2013 r.) w sprawie rozważenia beatyfikacji Witolda Pileckiego jest Michał Tyrpa, prezes krakowskiej Fundacji Paradis Judaeorum. Jest to jeden z elementów rozbudowanego projektu „Przypomnijmy o Pileckim” („Let's Reminisce about Witold Pilecki”), realizowanego od $2008 \mathrm{r}$.
} 
Intensyfikacja zabiegów mających na celu upamiętnienie Pileckiego uderza czasem rykoszetem w szeroko rozumianą polską pamięć historyczną, gdy towarzyszą im spory polityczne czy ideologiczne. Niezależnie od nich zgodność co do tego, że Pilecki jest bohaterem narodowym, stanowi często jedyny wspólny mianownik łączący wszystkie opcje polityczne.

W powszechnej świadomości Witold Pilecki występuje przede wszystkim jako „ochotnik do Auschwitz” oraz „autor pierwszego raportu o Holokauście”. Określenia te zostały wprowadzone do obiegu przez autorów pierwszych publikacji na jego temat. Ich powielenie, a zrazem utrwalenie w kolejnych biografiach Pileckiego spowodowało, że zaczęły funkcjonować jako synonimy jego nazwiska. Stały się także nieodłączną częścią bohaterskiej legendy Pileckiego, w której znalazły się też elementy idealizujące oraz uproszczenia. Jak zatem należy traktować te dwa popularne sformułowania? Przyjrzenie się biografii Pileckiego w kontekście tych określeń posłuży mi przy próbie odpowiedzi na to pytanie.

Witold Pilecki, późniejszy najbardziej znany rotmistrz kawalerii Wojska Polskiego, przyszedł na świat 13 maja 1901 r. w Ołońcu w północno-zachodniej Rosji, dokąd jego przodkowie zostali przesiedleni z terenów Litwy w ramach represji za udział w powstaniu styczniowym. Witold był jednym z pięciorga dzieci Juliana Pileckiego - rewizora leśnego, i Ludwiki Osiecimskiej. W 1910 r. w celu podjęcia nauki w polskiej szkole wraz z matką i rodzeństwem zamieszkał w Wilnie, podczas gdy ojciec z przyczyn materialnych pozostał w Ołońcu ${ }^{3}$. W Wilnie po raz pierwszy zetknął się z tajnymi organizacjami, wstępując do zakazanego przez cara skautingu oraz konspiracyjnego Towarzystwa „Sokół”. Z chwilą wybuchu pierwszej wojny światowej miał za sobą trzy klasy wileńskiego gimnazjum i przebywał na wakacjach w Druskiennikach. W czasie wojny kontynuował naukę w Orle nad Oką, gdzie sformował pierwszy na tym terenie zastęp harcerstwa. W październiku 1918 r. Pilecki dołączył do grona uczniów Gimnazjum im. Joachima Lelewela w Wilnie oraz do konspiracyjnej Polskiej Organizacji Wojskowej.

Atmosfera w Wilnie w tym kluczowym dla miasta i Polaków okresie pchnęła Pileckiego do włączenia się w szeregi Samoobrony Wileńskiej, wchodzącej w skład Wojska Polskiego. Następnie jako kawalerzysta brał udział m.in. w walkach pod Grodnem, w bitwie warszawskiej i obronie Wilna. Po zakończeniu wojny z bolszewikami zdał maturę i kontynuował służbę wojskową, która doprowadziła go do otrzymania w 1926 r. promocji na stopień podporucznika rezerwy ze starszeństwem od 1923 r. Osiadł w rodzinnym majątku w Sukurczach położonym koło Lidy (obecnie Białoruś), będącym posagiem jego prababki - Marii z domu Domcyk ${ }^{4}$. W 1931 r. ożenił się z Marią Ostrowską. Rok później przyszedł na świat pierworodny Pileckiego - Andrzej, a w 1933 r. córka Zofia. W dalszym

\footnotetext{
${ }^{3}$ Wiesław Jan Wysocki, Rotmistrz Witold Pilecki 1901-1948, Warszawa: Światowy Związek Żołnierzy Armii Krajowej i Oficyna Wydawnicza Rytm, 2009, s. 12-14.

${ }^{4}$ Ibidem, s. 26.
} 
ciągu aktywnie działał na polu wojskowym oraz społecznym. Zainicjował utworzenie Konnego Przysposobienia Wojskowego „Krakus”, złożonego z wojskowych osadników powiatu lidzkiego, po czym otrzymał dowództwo nad Lidzkim I Szwadronem PW, który w 1937 r. został podporządkowany 19 Dywizji Piechoty. Angażował się również w życie lokalnej społeczności - założył kółko rolnicze oraz objął prezesurę w (powołanej przez siebie) mleczarni. Za swoją wielotorową działalność został odznaczony w 1938 r. Srebrnym Krzyżem Zasługi.

Podczas kampanii wrześniowej Pilecki w stopniu podporucznika rezerwy brał udział w walkach 19 Dywizji Piechoty Armii „Prusy”, a następnie 41 Dywizji Piechoty Rezerwy, w której poznał mjr. Jana Włodarkiewicza, komendanta kawalerii dywizyjnej, i został mianowany jego zastępcą ${ }^{5} 22$ września, po rozbiciu 41 Dywizji, Pilecki i mjr Włodarkiewicz nie zastosowali się do rozkazu naczelnego wodza gen. Edwarda Śmigłego-Rydza o wycofaniu się przez Rumunię i Węgry do Francji. Obaj pozostali w kraju i podjęli inicjatywę konspiracyjną. W celu przeprowadzenia akcji werbunkowej do tworzonej organizacji wojskowej 9 listopada 1939 r. odbyło się zebranie konspiratorów, którzy zgłosili mjr. Włodarkiewiczowi chęć podjęcia współpracy. Tego dnia w warszawskim mieszkaniu szwagierki Pileckiego Eleonory Ostrowskiej uczestnicy zebrania: mjr Włodarkiewicz, ppor. Pilecki, ppor. Jerzy Maringe, inż. Jerzy Skoczyński oraz bracia Jan i Stanisław Danglowie, podjęli decyzję o utworzeniu Tajnej Armii Polskiej ${ }^{6}$. TAP w zamierzeniu mjr. Włodarkiewicza, który został jej komendantem, miała być organizacją wojskową o wyraźnym charakterze społeczno-ideologicznym opartym na wartościach chrześcijańskich. W związku z tym szeregi organizacji zasilali przede wszystkim studenci i żołnierze zawodowi wywodzący się ze środowisk chrześcijańskich, posiadający określone przez regulamin TAP kwalifikacje moralne i fachowe ${ }^{7}$.

Do zadań TAP należało prowadzenie działań wywiadowczo-dywersyjnych oraz społeczno-ideowych zgodnie z wyznaczonymi celami, takimi jak:

${ }^{5}$ Marco Patricelli, Ochotnik. O rotmistrzu Witoldzie Pileckim, tłum. Krzysztof Żaboklicki, Kraków: Wydawnictwo Literackie, 2011, s. 69-70.

${ }^{6}$ TAP deklarowała lojalność wobec polskiego rządu na uchodźstwie, ale nie uznawała gen. Michała Tokarzewskiego-Karaszewicza (masona i teozofa) za reprezentanta tego rządu. Z tego powodu założyciele TAP nie przyłączyli się do pierwszej w okupowanej Polsce organizacji konspiracyjnej, jaką była Służba Zwycięstwu Polski. TAP należała do Centralnego Komitetu Organizacji Niepodległościowych oraz do Komitetu Porozumiewawczego Organizacji Niepodległościowych, a po jego rozwiązaniu - do Konfederacji Narodu, zrzeszającej część organizacji konspiracyjnych, które nie podporządkowały się Związkowi Walki Zbrojnej. Z KN wydzielono Konfederację Zbrojną z mjr. Włodarkiewiczem na czele. W wyniku prowadzonej przez KN akcji scaleniowej we wrześniu 1941 r. członkowie TAP weszli w skład ZWZ. Mjr Włodarkiewicz został pierwszym komendantem „Wachlarza” - działającej przy ZWZ organizacji dywersyjnej.

${ }^{7}$ Kazimierz Malinowski, Tajna Armia Polska-Znak-Konfederacja Zbrojna. Zarys genezy, organizacji i działalności, Warszawa: PAX, 1986, s. 25-27. 
1) Kontynuowanie walki o niepodległość i przeprowadzenie jej aż do ostatecznego zwycięstwa wszelkimi dostępnymi dla Nas środkami.

2) Wypracowanie programu Rzeczypospolitej, który by zapewnił jej odrodzenie moralne i polityczne, gospodarcze i kulturalne.

3) Moralne podtrzymywanie społeczeństwa w czasie okupacji i przygotowanie go do czekających zadań ${ }^{8}$.

W ramach działań wywiadowczo-dywersyjnych członkowie TAP zajmowali się m.in. zbieraniem informacji o ruchach wojsk przeciwnika oraz o produkcji przemysłowej na potrzeby armii niemieckiej, sporządzaniem kartoteki osób podejrzanych o kolaborację oraz volksdeutschów, a także gromadzeniem danych na temat represji stosowanych przez okupanta. W Warszawie TAP miała swoich informatorów w zakładach przemysłowych, lokalach gastronomicznych ${ }^{9}$ oraz wśród zwerbowanych funkcjonariuszy policji granatowej, którzy w miarę możliwości ostrzegali o planowanych przez Niemców łapankach, rewizjach czy blokadach.

Rygorystyczne instrukcje dotyczące zakonspirowania osób i prowadzonych działań oraz funkcjonowania komórek wywiadowczych nie były w stanie zapobiec aresztowaniom członków TAP.

Do sierpnia 1940 r. ich wpadki miały jednak charakter przypadkowy i nie wynikały z rozpracowania organizacji przez Gestapo. Pierwszym spośród członków TAP, który padł ofiarą aresztowania, był komendant kieleckiego oddziału TAP rtm. Janusz Poziomski. Do jego zatrzymania - najprawdopodobniej na skutek donosu - doszło w połowie lutego $1940 \mathrm{r}$. Gestapo nie powiązało go jednak z działalnością na rzecz TAP, dzięki czemu w niedługim czasie został warunkowo zwolniony ${ }^{10}$.

W Warszawie zatrzymania członków TAP były skutkiem narastającej od wiosny 1940 r. fali aresztowań domowych, łapanek ulicznych i obław. Podczas jednej z nich, trwającej od 27 do 30 kwietnia, w kawiarni Bodega przy Nowym Świecie

\footnotetext{
${ }^{8}$ Wysocki, Rotmistrz Witold Pilecki..., s. 36-39.

${ }^{9}$ Głównym punktem informacyjnym spośród lokali była kawiarnia Bodega, której współwłaścicielem był pchor. Andrzej Rutkowski (członek TAP), oraz utworzone przez Niemców w październiku 1940 r. (w miejsce Kasyna Oficerskiego) Kasyno Gry w al. Szucha. W obydwu lokalach część kelnerów i kelnerek współpracowała z wywiadem TAP (Malinowski, Tajna Armia Polska..., s. 54).

${ }^{10}$ Jego zwolnienie związane było z błędnym powiązaniem Poziomskiego z osobą płk. Tadeusza Komorowskiego „Bora”, stojącego wówczas na czele ZWZ Obszaru Kraków-Śląsk. Gestapo postanowiło uwolnić Poziomskiego za cenę doprowadzenia ich do Komorowskiego. Gwarancją wypełnienia przez niego zadania miało być życie 400 polskich zakładników zatrzymanych przez gestapowców. Poziomski nie dotarł do Komorowskiego (mało prawdopodobne, by go w ogóle szukał) i zaszył się w warszawskim podziemiu, dołączając do ZWZ-AK. Zginął pierwszego dnia powstania warszawskiego (Tadeusz Bór-Komorowski, Armia Podziemna, Warszawa 2009, s. 44-46).
} 
25 aresztowano pchor. rez. Rutkowskiego (działającego na terenie Warszawa-Śródmieście), kelnerów: Janusza Rotherta, Jerzego Gizowskiego, pchor. Stanisława Zielińskiego oraz zmierzającego do Bodegi Stanisława Karola Dangla. Ich zatrzymanie miało charakter prewencyjny i było związane ze zbliżającym się świętem 3 Maja. Niezdekonspirowani przez Gestapo, po kilku miesiącach znaleźli się na wolności ${ }^{11}$.

Mniej szczęścia miał dr Władysław Dering, odpowiedzialny za służbę zdrowia w Sztabie Głównym TAP, aresztowany w lipcu, prawdopodobnie w wyniku donosu złożonego przez swoją współpracującą z okupantem siostrzenicę ${ }^{12}$. Nie został jednak powiązany z TAP, a jego zatrzymanie na Pawiaku miało związek $\mathrm{z}$ nasilonymi represjami wymierzonymi w środowisko inteligenckie. Do sierpnia 1940 r. aresztowani w Warszawie przedstawiciele inteligencji byli przede wszystkim zabijani w masowych egzekucjach dokonywanych w ramach „nadzwyczajnej akcji pacyfikacyjnej" (tzw. akcji AB).

W tym okresie nie odchodziły natomiast (z jednym wyjątkiem) transporty więźniów do obozów koncentracyjnych ${ }^{13}$. Wraz z formalnym zakończeniem przez Niemców pod koniec lipca akcji AB to kacety miały stać się jednymi z głównych miejsc kaźni. Wiązało się to również z uruchomieniem KL Auschwitz, do którego pierwszy transport warszawski został skierowany 14 sierpnia $1940 \mathrm{r}^{14}$ Znaleźli się w nim dwaj czołowi członkowie TAP: szef Sztabu Głównego ppłk inż. Władysław Surmacki oraz dr Władysław Dering. W niedługim czasie dołączył do nich por. rez. Jerzy de Virion, którego zatrzymano na początku maja $1940 \mathrm{r}$. na terenie Słowacji podczas próby przedostania się do Francji. Za nielegalne przekroczenie granicy umieszczono go w nowosądeckim więzieniu ${ }^{15}$. Do KL Auschwitz trafił 30 sierpnia $1940 \mathrm{r}$. Żaden z nich nie został rozpoznany i swoimi zeznaniami nie zagroził dekonspiracji poszczególnych komórek organizacyjnych.

Kolejne uderzenie w TAP miało już charakter zaplanowany i zdaniem dr. Zygmunta Śliwickiego ${ }^{16}$ było związane z infiltracją komórki łączności wywiadu, której dokonał konfident Borys (Bogusław) Pilnik ${ }^{17}$. Wskutek jego działania

${ }^{11}$ Malinowski, Tajna Armia Polska..., s. 87-88.
${ }^{12}$ Ibidem, s. 88.
${ }^{13}$ Pierwszy transport z Warszawy, liczący około 1500 mężczyzn (więźniów Pawiaka), wyruszył 2 V 1940 r. do KL Sachsenhausen. Wśród wywiezionych znaleźli się przedstawiciele inteligencji, w tym księża, politycy, wojskowi oraz członkowie organizacji konspiracyjnych (Władysław Bartoszewski, 1859 dni Warszawy, Kraków: Znak, 2008, s. 151).

${ }^{14}$ Transport składał się z 513 więźniów Pawiaka oraz z 1153 mężczyzn - ofiar obławy z 12 sierpnia.

${ }^{15}$ Malinowski, Tajna Armia Polska..., s. 87.

${ }^{16} 26$ IX 1940 r. został osadzony na Pawiaku, w którym do końca lipca 1944 r. pełnił funkcję lekarza prowadzącego oddziału wewnętrznego. Zob. Zygmunt Śliwicki, Meldunek z Pawiaka, Warszawa: PWN, 1974.

${ }^{17}$ Borys Pilnik, były aspirant straży więziennej, został za kolaborację i szmalcownictwo skazany wyrokiem Cywilnego Sądu Specjalnego na karę śmierci. Wyrok wykonano 25 VIII 1943 r. 
podczas obławy rozpoczętej 18 września 1940 r. niemiecka policja aresztowała kilku członków tej komórki, w tym por. rez. Konrada Żelechowskiego, który nie wytrzymawszy brutalnego przesłuchania, ujawnił znanych sobie TAP-owców (w tym Śliwickiego) i ich punkty kontaktowe. 19 i 20 września Gestapo kontynuowało obławę w lokalach TAP, w których aresztowano kilkanaście osób (kobiet i mężczyzn) ${ }^{18}$. Niewielu z nich zostało zwolnionych po przesłuchaniu. Część więziono na Pawiaku. Pozostałych wywieziono do obozów koncentracyjnych Auschwitz i Ravensbrück.

Wśród ponad 2 tys. mężczyzn aresztowanych 19 września znalazł się również Witold Pilecki („Witold”), który w TAP pełnił m.in. funkcję inspektora organizacyjnego i szefa Sztabu Głównego (od 25 listopada 1939 do maja 1940 r.) ${ }^{19}$. Tego dnia Niemcy prowadzili obławę głównie w dzielnicach zamieszkanych przez inteligencję: na Żoliborzu, Kolonii Staszica, Kolonii Lubeckiego, Ochocie. Tak te wydarzenia wspomina kronikarz okupowanej Warszawy Ludwik Landau:

[...] Obławy odbyły się z samego rana, o godz. 5-7; odbyły się w ten sposób, że obstawiono domy, po czym obchodzono mieszkanie za mieszkaniem - wymagało to użycia wielkiej ilości sił policyjnych [...]. W wyniku rewizji przeprowadzonych bardzo starannie w mieszkaniach, we wszystkich ubikacjach itd., zatrzymano wszystkich mężczyzn w wieku od 18 do 45 lat [...]. Przy okazji sprawdzano dowody rejestracji oficerów. Charakter obław można by więc, jak się zdaje, określić w ten sposób, że było to łapanie na roboty, ale z szukaniem przy tej sposobności osób podejrzanych politycznie i z wybraniem „podejrzanego" środowiska - inteligencji ${ }^{20}$.

Pileckiego zatrzymano we wspomnianym już mieszkaniu Eleonory Ostrowskiej przy al. Wojska Polskiego 40a/7 na Żoliborzu, w którym często przebywał od listopada 1939 r. Mimo że był jednym z wielu aresztowanych w tym dniu mężczyzn, jego zatrzymanie miało mieć zupełnie inny kontekst.

Po aresztowaniu dwóch członków TAP ze szczebla kierowniczego - dr. Deringa i ppłk. Surmackiego - mjr Włodarkiewicz zwołał pod koniec sierpnia $1940 \mathrm{r}$. naradę sztabu. To właśnie wtedy, zdaniem Kazimierza Malinowskiego, ówczesnego szefa łączności w Sztabie Głównym, miała paść propozycja, by ktoś z kierownictwa TAP przedostał się do KL Auschwitz „w celu wysondowania możliwości uwolnienia (ucieczka, odbicie itd.) niektórych więźniów, zdobycia materiałów dotyczących złego traktowania więźniów politycznych przez Niemców (i następnie ich przekazania Rządowi RP w Londynie), zorganizowania podziemnej organizacji wewnątrz obozu. Do wykonania zadania zgłosił się ochotniczo

\footnotetext{
${ }^{18}$ Malinowski, Tajna Armia Polska..., s. 94-95.

${ }^{19}$ Od sierpnia 1940 r. odpowiadał również za Oddział I (organizacyjno-mobilizacyjny) oraz za uzbrojenie Oddziału IV (zaopatrzenia i służb specjalnych).

${ }^{20}$ Ludwik Landau, Kronika lat wojny i okupacji, t. 1: Wrzesień 1939-listopad 1940, Warszawa: PWN, s. 694.
} 
por. Witold Pilecki, a mjr Włodarkiewicz wyraził zgodę na tę kandydaturę"21. Jednak zdaniem Adama Cyry ${ }^{22}$, który powołał się na protokół zeznań Pileckiego z 18 czerwca 1948 r., zadanie to zostało Pileckiemu narzucone przez mjr. Włodarkiewicza: „Wyjaśniam, że do tego kroku n a k ł o n i ł m n i e [podkreślenie moje - E.C.S.] mjr Włodarkiewicz Jan przez oświadczenie mi, że wymienił on moje nazwisko przed płk. Roweckim ps. Grot, który był wówczas głównym komendantem ZWZ, jako człowieka, który zdecydowałby się wejść do pierwszego z brzegu obozu i zorganizować tam pracę konspiracyjną"23. Ze względu na specyfikę materiałów śledczych Ministerstwa Bezpieczeństwa Publicznego można by zakwestionować prawdziwość zacytowanych słów, gdyby nie to, że znajdują one potwierdzenie we wspomnieniach Pileckiego napisanych w październiku 1945 r. podczas pobytu we Włoszech. Według nich już na początku sierpnia 1940 r. Włodarkiewicz zapowiedział „Witoldowi”: „[...] spotkał Ciebie zaszczyt, Twoje nazwisko wymieniłem $\mathrm{u}$ «Grota» jako jedynego oficera, który tego dokona”24. Jak podaje Pilecki, „chodziło o dostanie się do obozu j a k i e g o ś [podkreślenie moje - E.C.S.] i poprowadzenie tam pracy wśród Polaków, którzy podobno tam niezorganizowani giną" ${ }^{25}$. Wynika z tego, że Pilecki nie był - jak się przyjęło powszechnie uważać - inicjatorem przedostania się do obozu. Dlatego też właściwsze jest traktowanie misji „Witolda” w kategorii realizowania rozkazu przełożonych niż uznanie jej za dobrowolne poświęcenie.

Co więcej, w raporcie z 1945 r. Pilecki uczynił aluzję, że powodem, dla którego powierzono mu misję przedostania się do KL Auschwitz, mogła być niezgodność między nim a mjr. Włodarkiewiczem w kwestii podporządkowania TAP strukturom ZWZ, na co major nie wyrażał zgody ${ }^{26}$. Sugerowałoby to, że Pilecki

${ }^{21}$ Malinowski, Tajna Armia Polska..., s. 100-101; por. J. Garliński, Oświęcim walczący, Warszawa: Oficyna Wydawnicza Volumen, 1992, s. 29-30; Adam Cyra, Wiesław J. Wysocki, Rotmistrz Witold Pilecki, Warszawa-Oświęcim: Oficyna Wydawnicza Volumen i Fundacja Pamięci Ofiar Obozu Zagłady Auschwitz-Birkenau, 1997, s. 54.

${ }^{22}$ Dr Adam Cyra jest wieloletnim pracownikiem Centrum Badań w Państwowym Muzeum Auschwitz-Birkenau oraz autorem licznych publikacji (książek i artykułów) na temat Witolda Pileckiego. Postać Pileckiego była również tematem jego dysertacji doktorskiej („Rotmistrz Witold Pilecki [1901-1948]. Życie i działalność na tle epoki”), obronionej w 1996 r.

${ }^{23}$ Adam Cyra, Ochotnik do Auschwitz. Witold Pilecki 1901-1948, Oświęcim: Chrześcijańskie Stowarzyszenie Rodzin Oświęcimskich, 2000, s. 60-61. Por. też Michael Fleming, Auschwitz, the Allies and Censorship of the Holocaust, New York: Cambridge University Press, 2014, s. 26.

0 misji Witolda Pileckiego wspomniał również jego adwokat mec. L. Buszkowski w liście z 4 V 1948 r. do prezydenta Bolesława Bieruta: „Przybył z własnej woli, na rozkaz gen. «Grota», aby tam zorganizować pracę wojskową” (Wysocki, Rotmistrz Witold Pilecki..., s. 183).

${ }^{24}$ Archiwum Państwowego Muzeum Auschwitz-Birkenau (dalej APMA-B), Wspomnienia, t. 179, Witold Pilecki (wspomnienia obejmujące okres od dzieciństwa do aresztowania 19 IX 1940 r.), k. 313.

${ }^{25}$ Ibidem.

${ }^{26}$ W trakcie pobytu w KL Auschwitz Witold Pilecki jesienią 1941 r. otrzymał awans na porucznika. Przy tej okazji w raporcie z 1945 r. odniósł się do przyczyn swojej obecności 
mógł paść ofiarą rozgrywek wewnątrz TAP ${ }^{27}$. Trudno jednak tę tezę udowodnić. Rok po aresztowaniu Pileckiego Włodarkiewicz zdecydował o włączeniu organizacji do ZWZ. Wcześniej współpracował z ZWZ, odkąd Rowecki został jej komendantem, starając się jednocześnie zachować niezależność. Nie są do końca jasne powody włączenia TAP w struktury ZWZ. Być może przyczyniło się do tego osłabienie pionu dowódczego organizacji, spowodowane aresztowaniem czołowych członków TAP.

Zastanawiająca jest również sama idea celowego przeniknięcia do nowo otwartego KL Auschwitz. Przed utworzeniem tego obozu Polaków transportowano głównie do KL Dachau i KL Sachsenhausen, a mimo to żadna z podziemnych organizacji nie podjęła się wysłania do któregoś z nich swojego wysłannika. Ponadto KL Auschwitz nie był pierwszym obozem koncentracyjnym utworzonym na ziemiach polskich, a jednak to on, decyzją z początku sierpnia 1940 r. (niespełna dwa miesiące od pierwszego transportu więźniów politycznych Polaków), miał zostać rozpracowany przez polskie podziemie. Można to tłumaczyć chęcią zorientowania się w położeniu osadzanych w nim więźniów oraz brakiem wyobrażenia o warunkach panujących w obozie. Według Jana Masłowskiego: „[...] wieści o przygotowaniach do stworzenia tego obozu, o zwożeniu materiałów budowlanych, adaptacjach itp. docierały na Śląsk, do Krakowa i dalej" ${ }^{28}$. Były to jednak informacje szczątkowe i niepotwierdzone. Nie wskazywały również na eksterminacyjny charakter obozu. Władysław Bartoszewski ${ }^{29}$, zapytany, czy latem 1940 r. słyszał o obozie w Oświęcimiu, odpowiedział: „Nie.

w obozie: „Tymczasem - na ziemi, daleko, w Warszawie - awansowano mnie. Za montowanie TAP-u, za pracę nad zespoleniem w KZN. Za przekreślenie ambicji własnych i z chwilą obejrzenia upoważnienia gen. Sikorskiego, za dążenie do podporządkowania wszystkich oddziałów ZWZ-owi, co było pierwszym powodem niezgody z 82 [mjr Jan Włodarkiewicz - E.C.S.], a kto wie, może powodem, dlaczego znalazłem się poza Warszawą" (APMA-B, Wspomnienia, t. 130, Witold Pilecki [raport z 1945 r.], k. 44).

${ }^{27}$ Podobnego zdania jest Michael Fleming, profesor historii w Polskim Uniwersytecie na Obczyźnie w Londynie. Na podstawie raportu z 1945 r. oraz protokołu przesłuchania Pileckiego przez Eugeniusza Chimczaka 8 V 1947 r. Fleming uznał, że mjr Włodarkiewicz powierzył misję przedostania się do KL Auschwitz akurat Pileckiemu, powodowany sporem między nimi na temat dalszego kierunku działania TAP. Pilecki, który dążył do zniesienia ideologicznego charakteru organizacji oraz do włączenia jej w struktury ZWZ-AK, będąc w KL Auschwitz tracił bezpośredni wpływ na kwestie związane z TAP. Zob. Fleming, Auschwitz..., s. 312-313 (przyp. 47). W zeznaniu Pilecki stwierdza: „Na skutek potrzeby wszczęcia pracy organizacyjnej wśród Polaków wywożonych przez Niemców do r ó ż n y c h o b o z ó w , dowódca TAP Jan Włodarkiewicz zaproponował pułkownikowi Roweckiemu, dowódcy ZWZ, mnie jako w y t y p o w a n e g o [podkreślenia moje - E.C.S.] na ten cel oficera" (faksymile dokumentu [w:] Rotmistrz Witold Pilecki (1901-1948), oprac. Jacek Pawłowicz, Warszawa: IPN, 2008, s. 158-159).

${ }^{28}$ Jan Masłowski, Oświęcim. Cmentarz świata, Warszawa: Książka i Wiedza, 1995, s. 31.

${ }^{29}$ Władysław Bartoszewski został wywieziony do KL Auschwitz tzw. drugim transportem warszawskim 22 IX $1940 \mathrm{r}$. W obozie przebywał do 8 IV $1941 \mathrm{r}$. 
Myślę, że w Warszawie mało kto o nim wiedział. Może rodziny więźniów Pawiaka przywiezionych tam w sierpniu wraz z ludźmi z łapanki? Ja nie słyszałem, moje otoczenie też nie"30.

Pozostaje zatem sądzić, że gdyby przełożeni Pileckiego zdawali sobie sprawę ze skali niebezpieczeństwa, na jakie był on narażony, przekraczając bramę obozu, nie zdecydowaliby się na jego misję. Jeszcze trudniej zrozumieć zasadność tej decyzji w kontekście późniejszych wydarzeń. Od 15 sierpnia 1940 r. w KL Auschwitz przebywali przecież ppłk Surmacki (nr 2795) oraz dr Dering (nr 1723). Surmackiego skierowano do obozowego biura budowlanego (Baubiuro), w którym brał udział w przygotowywaniu planów technicznych obozu, obiektów i dróg. Dzięki temu miał możliwość pracy poza obozem i nawiązania kontaktów z miejscową ludnością. Deringa przydzielono do komanda budującego drogę. $\mathrm{Z}$ powodu choroby i wycieńczenia $\mathrm{w}$ niedługim czasie trafił on do obozowego szpitala. Po podleczeniu wszedł w skład jego personelu. Obaj mieli sporo szczęścia, mogąc pracować pod dachem, w stosunkowo bezpiecznych warunkach ${ }^{31}$.

Tymczasem pomimo możliwości, jakimi dysponowali, oraz ich konspiracyjnego doświadczenia kierownictwo TAP - nie wiedzieć czemu - nie powierzyło im zadania, by zorganizowali obozowy ruch oporu. Zamiast tego zdecydowano się wysłać w tym celu jednego ze swoich najważniejszych członków, co jeszcze bardziej nadwyrężało strukturę TAP, znacznie już osłabioną w wyniku wcześniejszych aresztowań. Poza tym, jeśli weźmie się pod uwagę rangę informacji, jakimi dysponował Pilecki o organizacji, niezmiernie ryzykowne było narażenie go na ewentualne przesłuchanie przez Gestapo, które mogło zakończyć jego misję i zagrozić zdekonspirowaniem TAP.

Przed rozpoczęciem misji ustalono sposób przedostania się do obozu, kwestię łączności oraz główne zadania, jakie miał wykonać na jego terenie. W ramach przygotowań Pilecki przybrał nową tożsamość, legitymując się dokumentami wystawionymi na oficera Tomasza Serafińskiego, którego błędnie uznano za nieżyjącego. Według planu drogą do KL Auschwitz miała być trwająca od 18 września obława.

W tym miejscu należy zwrócić uwagę, że w literaturze przedmiotu funkcjonują dwie odmienne wersje aresztowania Pileckiego. Część autorów powołuje się na powojenną relację Eleonory Ostrowskiej, inni zaś korzystają z informacji podanych przez samego Pileckiego we wspomnieniach spisanych w $1945 \mathrm{r}$.

\footnotetext{
${ }^{30}$ Michał Komar, Władysław Bartoszewski: skąd Pan jest? Wywiad rzeka, Warszawa: Świat Książki, 2006, s. 45.

${ }^{31}$ W wypadku ppłk. Surmackiego zachodziła obawa, że ze względu na posiadany stopień oficerski oraz przedwojenną działalność społeczną może znajdować się pod baczną obserwacją wydziału politycznego KL Auschwitz. Co prawda Surmackiego zwolniono z obozu w marcu 1942 r. (najprawdopodobniej po interwencji E. Fantiego, przewodniczącego Międzynarodowej Federacji Mierniczych), ale niedługo później został ponownie aresztowany. Zginął w zbiorowej egzekucji w maju lub lipcu 1942 r. (Malinowski, Tajna Armia Polska..., s. 100).
} 
Zasadnicza kwestia to przede wszystkim miejsce zatrzymania „Witolda”. Ponadto przez interpretację i rozbudowę historii zawartej w relacji Ostrowskiej i we wspomnieniach Pileckiego obydwie wersje dotyczące okoliczności aresztowania „Witolda” uległy dodatkowemu przekształceniu.

Z pozoru najwięcej zastrzeżeń mogą wzbudzać przedstawione przez Ostrowską okoliczności zatrzymania „Witolda”. Zastanawiające są przyczyny braku spójności między relacją Ostrowskiej a sprawozdaniem Pileckiego, w tym motywy całkowicie odmiennego przedstawienia przebiegu wydarzeń. Utrudnia to określenie stopnia wiarygodności i przydatności przekazu Ostrowskiej. Do tego Ostrowska złożyła kilka relacji (autorzy, którzy się na nie powołują, nie podają niestety dat ich składania), które - co charakterystyczne dla tego rodzaju źródła - różnią się między sobą kilkoma szczegółami32.

Na podstawie jednej z jej relacji moment zatrzymania Pileckiego opisał Kazimierz Malinowski: „Kiedy im otworzyła drzwi [Eleonora Ostrowska], zapytali, czy w mieszkaniu znajdują się mężczyźni. Widać przy tym było, że zadowoliliby się również odpowiedzią negatywną. Tymczasem z głębi mieszkania wyszedł do nich Pilecki. Wylegitymowali go, a ponieważ nie miał zaświadczenia z pracy, został zatrzymany"33. Przekaz ten kłóci się nieco z przytoczonym wcześniej opisem obławy zamieszczonym w dzienniku Landaua z 19 września, z którego otrzymujemy całkowicie odmienny obraz wydarzeń ${ }^{34}$. Wynikałoby z niego, że w niektórych przypadkach niemieckim funkcjonariuszom nie zależało na skrupulatnym rewidowaniu mieszkań oraz że zorganizowana na tak szeroką skalę obława była przeprowadzana pobieżnie.

Inną wersję zatrzymania „Witolda” przedstawiają Adam Cyra oraz Wiesław Jan Wysocki ${ }^{35}$ :

Wcześnie rano 19 września 1940 r. Witold był w moim mieszkaniu. Dozorca Jan Kiliański, zaprzysiężony żołnierz TAP, przyszedł do mnie i oznajmił mi, że jesteśmy otoczeni przez umundurowanych Niemców, którzy z każdego domu wyprowadzają mężczyzn i ładują na samochody. Podał

${ }^{32}$ Ostrowska zdała relację z zatrzymania Pileckiego kilku osobom, w tym Kazimierzowi Malinowskiemu, Wiesławowi J. Wysokiemu i Adamowi Cyrze, którzy zacytowali jej fragmenty w swoich publikacjach. Treść relacji złożonej Cyrze znajduje się w Archiwum Państwowego Muzeum Auschwitz-Birkenau (APMA-B, Wspomnienia, t. 179, Eleonora Ostrowska, k. 144158), pozostałe są tylko w posiadaniu ww. autorów.

${ }^{33}$ Malinowski, Tajna Armia Polska..., s. 102.

${ }^{34}$ Przedstawiony przez Landaua bieg wydarzeń potwierdzają także słowa Władysława Bartoszewskiego, który sam padł ofiarą obławy z 19 września: „Po mnie przyszli o świcie, do mieszkania. Krzyki Aufstehen, mitkommen! Szczelnym kordonem otoczyli blok przy ulicy Słowackiego 35/43 [na Żoliborzu - E.C.S.], gdzie z rodzicami mieszkałem na parterze. Do Auschwitz wywieźli z naszego domu w sumie czternastu mężczyzn" (Władysław Bartoszewski, Mój Auschwitz, Kraków: Znak, 2010, s. 13).

${ }^{35}$ Prof. dr hab. Wiesław Jan Wysocki jest autorem pierwszej monografii o Witoldzie Pileckim (Rotmistrz Pilecki) opublikowanej w 1994 r. 
też Witoldowi wiele możliwości uniknięcia branki. Witold odrzucił te propozycje i nie chciał nawet próbować ukryć się w moim mieszkaniu. Po chwili energicznie zastukano do drzwi. Otworzyłam i w drzwiach stanął niemiecki żołnierz - zapytał, kto tu mieszka. Nie zdążyłam odpowiedzieć, gdyż w tej chwili z pokoju wyszedł Witold. Niemiec nie legitymował go. Witold ubrał się i żegnając ze mną, szepnął: «Zamelduj gdzie trzeba, że rozkaz wykonałem» $[. . .]^{36}$.

Przytoczone słowa oznaczają, że Ostrowska nie została wtajemniczona w plany Pileckiego. Wyjaśnia to charakterystyczny dla jej relacji brak zrozumienia przyczyn jego zachowania podczas obławy, dzięki czemu został aresztowany „jako jeden z wielu”, nie wzbudzając podejrzeń policji niemieckiej. Ten brak wiedzy tłumaczy również przecenienie przez Ostrowską możliwości uniknięcia przez Pileckiego zatrzymania, bo w jakiej mierze realne były rzeczywiste szanse ucieczki? Jeśli ostrzeżenie o łapance przyszło już po otoczeniu przez Niemców budynku i okolicy, powodzenie takiej ucieczki było niewielkie. Nieskuteczne mogłoby być również ukrycie się w mieszkaniu, ze względu na prawdopodobieństwo rewizji. Z kolei ewentualne odkrycie takiej kryjówki naraziłoby na poważne konsekwencje nie tylko Pileckiego, lecz także Ostrowską. Mało prawdopodobne, by Pilecki ryzykował życie swojej szwagierki.

Znacznie bardziej ogólnikowo okoliczności swojego zatrzymania przedstawił sam Pilecki. W raporcie opracowanym w czerwcu 1943 r. w Nowym Wiśniczu zupełnie je pominął, pisząc jedynie: „Podjąłem pracę w Oświęcimiu, gdzie przyjechałem z kpt. Trojnickim «Fred» warszawskim [transportem] w nocy z dnia 21-22 września 1940"37. W szkicu do przyszłego pamiętnika napisanego w październiku 1945 r. w San Giorgio we Włoszech poświęcił im więcej miejsca: „Po pierwszej «łapance» w Warszawie w sierpniu 1940 r. [12 sierpnia -E.C.S.] «Jan» [mjr Jan Włodarkiewicz - E.C.S.] powiedział do «Witolda»: «Ot, widzisz, nie skorzystałeś z takiej dobrej okazji dostania się w 'niewinny' sposób do obozu. Nie miałbyś sprawy, nic by ci nie mogli zarzucić». Więc «Witold» skorzystał z drugiej okazji 19 września 1940 r."38.

Dopiero w obszernym sprawozdaniu na temat pobytu w KL Auschwitz i konspiracji wojskowej w obozie Pilecki zdecydował się podać szczegóły swojego zatrzymania: „Dnia 19 września 1940 r. - druga łapanka w Warszawie. Jeszcze żyje kilku ludzi, którzy widzieli, jak o godzinie 6 rano poszedłem sam i na rogu al. Wojska i Felińskiego stanąłem w «piątki» ustawiane przez SS-manów z łapanych mężczyzn. Potem załadowano nas na pl. Wilsona do aut ciężarowych i zawieziono do koszar Szwoleżerów"39.

\footnotetext{
${ }^{36}$ Cyra, Wysocki, Rotmistrz..., s. 54-56.

${ }^{37}$ APMA-B, Wspomnienia, t. 130, Witold Pilecki (raport z czerwca 1943 r.), k. 110.

${ }^{38}$ Ibidem, t. 179, Witold Pilecki (wspomnienia obejmujące okres od dzieciństwa do aresztowania 19 IX 1940 r.), k. 313.

${ }^{39}$ Ibidem, t. 130, Witold Pilecki (raport napisany w 1945 r. we Włoszech), k. 1.
} 
Pierwszym historykiem, który nawiązał do tego raportu, był Józef Garliń$\mathrm{ski}^{40}$, autor opublikowanej w Londynie w 1974 r. książki Oświęcim walczacy. Już we wstępie Garliński podkreślił, że:

znaczną część mojej pracy mogłem oprzeć na zupełnie unikalnej relacji, która znajduje się w Studium Polski Podziemnej w Londynie. Napisał ją w r. 1946 [powinno być: 1945 r. - E.C.S.] Witold Pilecki, twórca ruchu podziemnego w oświęcimskim obozie, który poszedł tam dobrowolnie, by zbudować konspiracyjną organizację wojskową. Wielokrotne sprawdzanie osoby autora, jego przeszłości i jego ideowego nastawienia pozwoliły mi stwierdzić, że relacja jest na pewno uczciwa i że fakty są w niej przedstawione wiernie. Niemniej sprawdzałem ją wielokrotnie i konfrontowałem z innymi źródłami ${ }^{41}$.

Z tego też powodu Garliński w swojej książce odtworzył okoliczności aresztowania Pileckiego właśnie na podstawie jego wspomnień. Popularność publikacji Garlińskiego wpłynęła na utrwalenie wersji o dobrowolnym przyłączeniu się Pileckiego do grupy mężczyzn aresztowanych podczas łapanki na Żoliborzu. Z czasem przybrała ona formę legendy, do której dołączano kolejne „fakty”.

Najlepszym tego przykładem jest opis zatrzymania Pileckiego przedstawiony w książce Marco Patricellego. Wynika z niego, że pomimo okrzyków ostrzegających o łapance Pilecki świadomie wszedł w sam jej środek, po czym „Gardłowe krzyki żołnierzy zmuszają go do zatrzymania się, wymierzone w niego karabiny świadczą, że nie pora na dyskusje. Mężczyzna podnosi ramiona do góry i zostaje wepchnięty między ludzi stojących ze splecionymi na karku rękami" ${ }^{2}$.

Jeszcze inaczej przebieg zdarzeń opisał w powojennych wspomnieniach Wincenty Gawron, który przez kilka tygodni dzielił obozowy siennik z Pileckim. Dzięki tej znajomości oraz udziałowi Gawrona w obozowym ruchu oporu Pilecki miał mu zdradzić kulisy swojego przedostania się do KL Auschwitz: „Dziewiętnastego września byłem na Żoliborzu, gdy ktoś nagle krzyknął: łapanka! W pierwszym, samozachowawczym odruchu skoczyłem na strych najbliższej kamienicy, gdzie się ukryłem. Po chwili zastanowienia postanowiłem zejść na dół prosto w łapy żandarmów"43.

${ }^{40} \mathrm{~W}$ czasie drugiej wojny światowej Józef Garliński brał udział w kampanii wrześniowej, następnie należał do ZWZ-AK, w której kierował wywiadem więziennym. Po aresztowaniu w kwietniu 1943 r. został przetransportowany do KL Auschwitz. Wyzwolenia doczekał w jednym z podobozów KL Neuengamme. Po zakończeniu wojny przebywał w Londynie, w którym w 1973 r. uzyskał tytuł doktora za rozprawę dotyczącą ruchu podziemnego w KL Auschwitz.

${ }^{41}$ Garliński, Oświęcim..., s. 10.

${ }^{42}$ Patricelli, Ochotnik. O rotmistrzu..., s. 87; por. Rotmistrz Witold Pilecki (1901-1948), s. 22.

${ }^{43}$ Wincenty Gawron, Ochotnik do Oświęcimia, Kraków-Oświęcim: Calvarianum i Wydawnictwo Państwowego Muzeum, 1992, s. 114. Wspomnienia Gawrona zostały wydane już po jego śmierci. W „Słowie od redakcji” podkreślono, że publikacja jest częścią pamiętnika prowadzonego przez Gawrona podczas okupacji i przez kilka lat po wojnie. Rozdział poświęcony wspomnieniom z pobytu w KL Auschwitz zatytułował on „Ochotnik do Oświęcimia”. 
Jak widać, większość przytoczonych wersji jest spójna z przedstawionymi przez Pileckiego okolicznościami zatrzymania. Ich autorzy potraktowali jego sprawozdanie jako w pełni wiarygodny materiał źródłowy, zwłaszcza że nie mieli powodów, by podważać jego prawdomówność. Tymczasem w opisie przebiegu aresztowania Pilecki - z sobie tylko znanych powodów - postanowił uciec się do konfabulacji ${ }^{44}$. Fakt ten poruszyła Ostrowska w jednej ze swoich relacji, w której zwróciła uwagę, „że w dotychczasowych opisach Witold ze względów konspiracyjnych nie podawał mojego adresu, skąd go zabrano" ${ }^{45}$. I tu przechodzimy do najważniejszej kwestii. Chociaż relacja Ostrowskiej sprowokowała najwięcej pytań, to właśnie ona przedstawia prawdziwą wersję wydarzeń z 19 września 1940 r. Jest ona spójna z biegiem wydarzeń przedstawionym przez Pileckiego we wspomnieniach spisanych w 1945 r. oraz z treścią protokołu jego zeznań z $1947 \mathrm{r}$. Wersję Ostrowskiej podtrzymuje także jej syn Andrzej ${ }^{46}$. Nie ma z kolei żadnych dowodów ani świadków na dołączenie Pileckiego do grupy aresztowanych.

Bez względu na rozbieżności dotyczące miejsca i okoliczności zatrzymania „Witolda” wszystkie wersje mają wspólny przekaz, na podstawie którego historycy (i nie tylko oni) uznali, że Pilecki, z zamiarem przedostania się do KL Auschwitz, dał się dobrowolnie ująć Niemcom. W wyniku późniejszej interpretacji i uproszczenia przekazu powstała obiegowa opinia określająca Pileckiego mianem „ochotnika do Auschwitz”.

Trudno jest ustalić autora tego sformułowania. W 1976 r. pojawiło się ono w tytule francuskojęzycznego wydania książki Garlińskiego (Volontaire pour Auschwitz: La Résistance organisée à l'intérieur du camp). W Polsce określenie to spopularyzował Wincenty Gawron, który swoje obozowe wspomnienia, w znacznej mierze poświęcone także Pileckiemu, zatytułował Ochotnik do Oświęcimia. W niedługim czasie zostało ono zapożyczone przez biografów Pileckiego. W ten sposób to zgrabne i wyraziste sformułowanie utrwaliło się za sprawą następujących publikacji: Adama Cyry (Ochotnik do Auschwitz, 2000), Marco Patricellego (Il Volontario, Rzym 2010, polskie tłumaczenie: Ochotnik. O rotmistrzu Witoldzie Pileckim, Kraków 2011) oraz The Auschwitz Volunteer: Beyond Bravery (Witold Pilecki, tłum. Józef Garliński, Los Angeles 2012) ${ }^{47}$. Wynika to z tendencji do ujmowania opisywanych postaci i zjawisk w formie uproszczonej, niedostatecznej krytyki źródeł lub jej całkowitego braku oraz niedostrzeżenia sprzeczności w materiale faktograficznym. Konsekwencją tego stanu rzeczy w wypadku „ochotnika do Auschwitz” jest powszechne używanie określenia, którego treść tylko częściowo odpowiada faktom.

${ }^{44}$ Wysocki, Rotmistrz Pilecki, s. 44.

${ }^{45}$ APMA-B, Wspomnienia, t. 179, Eleonora Ostrowska, k. 148.

${ }^{46}$ Archiwum Historii Mówionej Ośrodka Karta, Relacja Andrzeja Ostrowskiego.

${ }^{47} \mathrm{~W}$ albumie wydanym przez IPN czytamy z kolei: „Za wiedzą Komendanta Głównego ZWZ AK [...] do wypełnienia tej misji [przeprowadzenia działań wywiadowczych na terenie obozu - E.C.S.] ochotniczo zgłosił się Witold Pilecki i 19 września 1940 r. podczas łapanki na warszawskim Żoliborzu, jako Tomasz Serafiński, pozwolił się aresztować" (Rotmistrz Witold Pilecki [1901-1948], s. 22). 
Jak już wcześniej zauważyłam, na podstawie materiału źródłowego nie można jednoznacznie uznać Pileckiego za inicjatora pomysłu przedostania się do KL Auschwitz i utworzenia w nim konspiracji wojskowej. Co więcej, z tego materiału wynika, że forma i okoliczności, w jakich powierzono mu to zadanie, nie dawały Pileckiemu nazbyt wielkich możliwości odmowy jego wykonania. Nie umniejsza to w żaden sposób jego bohaterstwa i zasług, wskazuje jedynie na nieadekwatne użycie określenia „ochotnik” w kontekście tamtych wydarzeń. Używając sformułowania „ochotnik do Auschwitz”, należy zdawać sobie sprawę, że Pilecki nie mógł mieć pewności, że wskutek wrześniowej obławy trafi akurat do KL Auschwitz. Do chwili jego aresztowania tylko jeden transport więźniów z Warszawy został skierowany do tego obozu i nie sposób było przewidzieć, kiedy i czy w ogóle będzie następny. Nie ma również dowodów na to, by wiedzę na ten temat miało polskie podziemie. Poza tym mężczyzn zatrzymanych 19 września następnego dnia przewieziono na dworzec kolejowy, skąd zostali rozesłani w trzech różnych kierunkach. Część spośród aresztowanych skierowano przecież do obozów pracy w zachodnich regionach Rzeszy, część wywieziono na roboty przymusowe do Prus Wschodnich, pozostałych, w tym Pileckiego, przetransportowano do KL Auschwitz ${ }^{48}$.

Należy raczej uznać, że zatrzymanie i wywiezienie do Auschwitz zostało wykorzystane przez „Witolda” jako szczęśliwy zbieg okoliczności umożliwiający mu podjęcie działań konspiracyjnych na terenie obozu. 0 tym, że jego trafienie do KL Auschwitz było zamierzone, a nie przypadkowe, miało świadczyć awansowanie go na porucznika 11 listopada $1941 \mathrm{r}$. (w czasie pobytu w obozie), ponieważ jak zauważył Wiesław Jan Wysocki, „w ZWZ-AK obowiązywała pragmatyka, iż z zasady nie awansowano i nie odznaczano więźniów"49.

W nocy z 21 na 22 września 1940 r. przyjechał do KL Auschwitz tzw. drugi transport warszawski, liczący 1705 więźniów. Witold Pilecki, który w obozie przebywał pod przybranym nazwiskiem Tomasz Serafiński (nr 4859), po trafieniu na jego teren przystąpił do tworzenia zrębów konspiracji wojskowej, by w ten sposób łączyć i podtrzymywać na duchu więźniów, organizować żywność i odzież, przygotowywać ucieczki oraz wysyłać do KG ZWZ (później AK) w Warszawie dokumenty, sprawozdania i meldunki opisujące obozową rzeczywistość. Utworzony za sprawą Pileckiego Związek Organizacji Wojskowej, którego struktura opierała się na zaprzysiężonych tajnych „piątkach”, po pewnym czasie wyznaczył sobie zadanie „przygotowania oddziałów własnych do opanowania obozu, gdy nadejdzie nakaz chwili w postaci rozkazu zrzucenia tu broni lub siły żywej (desantu)" ${ }^{50}$.

${ }^{48}$ Cyra, Ochotnik..., s. 64.

${ }^{49}$ Wysocki, Rotmistrz Pilecki, s. 41. Sprawa awansu nie jest do końca jasna, gdyż Bór-Komorowski awansował Pileckiego 19 II 1944 r. na rotmistrza kawalerii (odpowiednik kapitana) (Rotmistrz Pilecki Pilecki [1901-1948], s. 24).

${ }^{50}$ APMA-B, Wspomnienia, t. 130, Witold Pilecki (raport napisany w 1945 r. we Włoszech), k. 8. 
Wiadomości na temat tragicznego położenia więźniów KL Auschwitz oraz działań podejmowanych przez ZOW Pilecki przekazywał do Warszawy przede wszystkim za pośrednictwem osób zwalnianych z obozu, a od 1942 r., po zniesieniu odpowiedzialności zbiorowej za ucieczki, poprzez uciekinierów.

Pierwszy meldunek o eksterminacji wskutek morderczej pracy więźniów, bestialskich kar i głodowych racji żywieniowych Witold Pilecki przekazał do Warszawy przez zwolnionego z obozu w październiku 1940 r. Aleksandra Wielopolskiego (numer obozowy nieznany). Z inicjatywy komendanta ZWZ gen. Stefana Roweckiego „Grota” podziemie polskie na podstawie zebranych wiadomości opracowało w styczniu 1941 r. raport „0 terrorze i bezprawiach okupantów”, adresowany do gen. Kazimierza Sosnkowskiego (w tym czasie ministra w rządzie RP na uchodźstwie w Londynie), w którym poza informacjami dotyczącymi różnych form i metod hitlerowskich represji zawarto także opis KL Auschwitz. W części zatytułowanej „Obóz w Oświęcimiu” scharakteryzowano przyjęcie więźnia do obozu, harmonogram dnia, warunki obozowe, rodzaje wymierzanych kar oraz najczęstsze przyczyny zgonów. Raport dotarł do Londynu 18 marca $1941 \mathrm{r}^{51}$

16 maja 1942 r. z podobozu Harmense w Harmężach koło Oświęcimia uciekli dwaj członkowie ZOW: por. Wincenty Gawron (nr 11237) oraz Stefan Bielecki (członek TAP, nr 12692). Jak wspomina Gawron, Pilecki polecił im przekazanie dowództwu podziemia w Warszawie informacji o bieżącej sytuacji w obozie:

Musisz przekazać informację o tym, jak Niemcy traktują sowieckich jeńców. Jednak najważniejszą sprawą jest masowe wykańczanie Żydów. Daj dowództwu znać, że dzieci i starcy ze Słowacji zostali zagazowani, a młodzież obojga płci jest używana do ciężkich robót, co w konsekwencji wiedzie do komina. Nasze dowództwo musi zawiadomić Londyn, aby cały świat ratował Żydów od zguby. Teraz zaczęli wywozić Żydów z Belgii i Holandii [...]. Tych ludzi także trzeba ratowaćs2.

30 czerwca 1944 r. Bielecki, który miał dostarczyć ów raport Komendzie Głównej AK, złożył Pileckiemu następujące oświadczenie:

Otrzymawszy rozkaz od Witolda, wydostałem się z Oświęcimia 16 maja 1942 r. - dotarłem do Warszawy 30 czerwca 1942 r., gdzie złożyłem meldunek na piśmie na ręce 227 [prawdopodobnie chodzi o ppłk. Jerzego Uszyckiego - E.C.S.], któremu osobiście zdawałem sprawę ze stanu pracy organizacyjnej w obozie. Według oświadczenia raport został przedłożony Komendantowi „Grotowi”. Ponieważ od początku 1943 r. nie wezwano mnie celem podania szczegółów pracy, które mogłem podać tylko ustnie, zwróciłem się za pośrednictwem „Skiby” do Komendy Głównej celem

${ }^{51}$ Opublikowany w: Armia Krajowa w dokumentach 1939-1945, t. 1: Wrzesień 1939-czerwiec 1941, red. Tadeusz Pełczyński i in., Wrocław i in.: Ossolineum, 1990, s. 431-433.

${ }^{52}$ Gawron, Ochotnik..., s. 248;. por. APMA-B, Wspomnienia, t. 183, Witold Pilecki („Raport W"), k. 48, 70. 
wyjaśnienia tej zwłoki. Otrzymałem odpowiedź, że raport dotarł i że w razie potrzeby zostanę wezwany ${ }^{53}$.

Kolejny meldunek od „Tomasza Serafińskiego” przekazał komendanturze ZWZ-AK por. Stanisław Gustaw Jaster (nr 6438), który razem z trzema innymi więźniami KL Auschwitz dokonał brawurowej ucieczki z obozu 20 czerwca $1942 \mathrm{r}$.

W tym miejscu należy zaznaczyć, że żaden z wymienionych raportów się nie zachował. Trudno również ustalić, w jakim stopniu zostały one wykorzystane przez $\mathrm{KG} \mathrm{AK}^{54}$. Ze względu na wojskowy charakter misji Pileckiego oraz główne założenia ZOW można jednak stwierdzić, że intencją tych oraz następnych meldunków było przede wszystkim nakłonienie polskiego dowództwa do wyzwolenia KL Auschwitz siłą więźniów przy jednoczesnym wsparciu z zewnątrz, polegającym na zrzuceniu na jego teren broni albo przez ciężkie bombardowania esesmańskich magazynów i koszar. Pilecki ratunek dla więźniów widział również w połączeniu wszystkich obozowych organizacji konspiracyjnych, którym z pomocą miały przyjść okoliczne oddziały partyzanckie ${ }^{55}$.

Wbrew oczekiwaniom Pileckiego Warszawa milczała, nie wydając ZOW zezwolenia na podjęcie walki. Ten brak reakcji był jednym z powodów, dla których Pilecki, razem z Janem "Retko" (Janem Redzejem, nr 5430) i Edwardem Ciesielskim (nr 12969), zdecydował się na ucieczkę. W nocy z 26 na 27 kwietnia 1943 r. Ciesielski, „Retko” i Pilecki przebywali w komandzie piekarzy pracujących w więźniarskiej piekarni położonej poza obozem. Pod pretekstem przygotowania opału przeszli do drewutni, w której wykorzystując nieuwagę strażników, odkręcili nakrętki śrub mocujących metalowe drzwi i dorobionym kluczem

${ }^{53}$ W czerwcu i lipcu 1944 r. na końcu „Raportu W” kilku współpracowników Pileckiego, w tym Stefan Bielecki, własnoręcznie złożyło krótkie sprawozdania z powierzonej im misji (APMA-B, Wspomnienia, t. 183, Witold Pilecki [„Raport W”], k. 70).

${ }^{54} \mathrm{Na}$ podstawie relacji i raportów o KL Auschwitz obejmujących stan wiedzy o obozie do listopada 1940 r. został przygotowany trzystronicowy dokument zatytułowany „Oświęcim Concentration Camp”, kończący się słowami: „W listopadzie 1940 roku 8 tys. Polaków znajdowało się w obozie Oświęcim. Więźniów podzielono na trzy grupy: więźniów politycznych, kryminalistów, księży i Żydów. Ta ostatnia grupa była najbardziej prześladowana. Rzadko ktoś z niej wychodził żywy z obozu". Został on dołączony do noty przesłanej przez rząd polski w Londynie 3 V 1941 r. do państw sojuszniczych i neutralnych (Martin Gilbert, Auschwitz and the Allies, London: Michael Joseph, 2001, s. 15).

${ }^{55}$ Garliński, Oświęcim..., s. 165-167. Od 1940 do 1941 r. w obozie funkcjonowały konspiracyjne grupy tworzone przez wojskowych socjalistów i narodowców. W 1942 r. w wyniku akcji scaleniowej utworzono jednolitą organizację, którą nazwano Armią Krajową. Poza AK pozostały grupy lewicowe. W 1943 r. część z nich utworzyła międzynarodową organizację Kampfgruppe Auschwitz. W 1944 r. dołączyły do niej polskie grupy wojskowe. W ten sposób powstała Rada Bojowa Oświęcimia. Od przełomu 1942 i 1943 r. w obozie funkcjonowały także grupy więźniów różnych narodowości oraz organizacje żydowskie. W 1944 r. powołano Radę Wojskową Oświęcim, obejmującą polskie grupy wojskowe oraz grupy lewicowe. 
przystąpili do otwierania drzwi. Zanim uciekli, zdążyli jeszcze odciąć przewód dzwonka alarmowego. Pozostawiwszy zabarykadowanych od zewnątrz esesmanów, skierowali się na wschód i po kilkunastu godzinach przekroczyli granicę Generalnego Gubernatorstwa ${ }^{56}$.

Będąc już na wolności, w czerwcu 1943 r. w Nowym Wiśniczu napisał swój pierwszy - wspominany wcześniej przeze mnie - raport z pobytu w KL Auschwitz, który potraktował jako nieformalne wspomnienia obozowe. Liczący jedenaście stron maszynopis Pilecki postanowił zakopać na terenie gospodarstwa Ludmiły Serafińskiej, u której otrzymał schronienie. Raport ten ujrzał światło dzienne dopiero po jego śmierci ${ }^{57}$.

W sierpniu 1943 r. w Warszawie Pilecki zaczął przygotowywać kilkudziesięciostronicowe sprawozdanie - „Raport W" - na temat konspiracji wojskowej w KL Auschwitz, przeznaczone dla Komendy Głównej AK. We wstępie Pilecki sprecyzował jego charakter:

Każdy z nas trzech napisał cząstkę tego, co przeżył i widział w Oświęcimiu. Pisząc, podzieliliśmy się pracą z „J" [Jan Redzej] i „E” [Edward Ciesielski] w ten sposób, że oni mieli dać ogólny obraz lagru, ja zaś chcę tu uwiecznić innego charakteru momenty [...]. Jakkolwiek - w opisach naszych - mogą być te lub inne braki, tak pod względem stylistycznym, jak i pominięcie niektórych obrazków z piekła, gdyż na kilkunastu stronach wszystko opisać się nie da, to jednak nie ma w tych wspomnieniach nieprawdy. Jest napisane o wiele mniej i ani słowa za wiele ${ }^{58}$.

Kwestie dotyczące członków i działalności ZOW zostały nakreślone na tle wydarzeń z życia obozu, ale z wyraźną przewagą szczegółowych informacji o działalności obozowego podziemia. Treść „Raportu W” wypełnia kompilacja trzech wątków: sprawozdanie z prac ZOW i jego członków, obozowe przeżycia Pileckiego i związane z tym refleksje oraz - w mniejszym stopniu - metody eksterminacji więźniów, w tym zbrodni popełnianych na Żydach. „Raportu W” nie można traktować jako raportu sensu stricto o Holokauście, ponieważ na kilkudziesięciu stronach informacje dotyczące traktowania Żydów i wskazujące na ich zagładę pojawiły się zaledwie kilka razy, bez wyróżnienia ich szczególnej sytuacji (z nie mniejszą częstotliwością wspomniane zostały losy różnych grup więźniów):

[...] Wyżej wymienione liczby stosują się do „Häftlingów” - po przywiezieniu normalnie zewidencjonowanych i oznaczonych kolejnym numerem więźnia. Natomiast nie obejmuje to ogromnej ilości ludzi, przywiezionych tu w celu natychmiastowego odebrania im życia, co odbywało się w odleg-

\footnotetext{
${ }^{56}$ Ibidem, s. 121-124.

${ }^{57}$ Według relacji Ludmiły Serafińskiej, żony prawdziwego Tomasza Serafińskiego, po wojnie Witold Pilecki poprosił ją o zniszczenie napisanych w Nowym Wiśniczu wspomnień, ponieważ - jak tłumaczył - napisał nowe, lepsze. Wspomnienia jednak ocalały, gdyż Serafińska nie zastosowała się do jego prośby (Cyra, Ochotnik..., s. 13).

${ }^{58}$ APMA-B, Wspomnienia, t. 183, Witold Pilecki („Raport W”), k. 2.
} 
łości paru kilometrów od obozu - w Brzezince - w pobliżu filii Oświęcimia - obozu w Rajsku, gdzie gazowano cale transporty ludzi, dostarczane tu pociągami i autami - czasami po parę tysięcy dziennie, a liczba których obliczona w cyfrach okrągłych w sierpniu 1942 r. przekraczała 800 tysięcy ludzi, a w marcu 1943 r. sięgała ponad półtora miliona ludzi ${ }^{59}$. Przeważali Żydzi, lecz byli również Czesi, Niemcy i inni ${ }^{60}$. [...]

Przechodzimy koło krematorium. Naprzeciwko wejścia stoi grupka mężczyzn i kobiet. Polacy. Wrażenie akurat takie, jak się widzi kilka kroków przed rzeźnią. Mój Boże - kobiety - Polki, zaraz, gdy tylko wejdziemy do lagru, poproszą ich żywcem do krematorium, dadzą im mydełko i ręcznik, a one i oni będą sądzili, że idą się kąpać (czasami nawet tej komedii nie stosują). [...]

Należy tu jeszcze chociaż w paru słowach podkreślić, co prawda nie wszystkich, dzielną postawę księży. Początkowo ksiądz w ogóle dłużej niż parę dni nie żył. Zabijano ich pałkami na placu (tak samo jak Żydów zaprzęgniętych do walca) ${ }^{61}$.

Pomimo rozpoczętej w 1942 r. akcji „ostatecznego rozwiązania kwestii żydowskiej", realizowanej także na terenie KL Auschwitz i związanego z nią masowego uśmiercania Żydów w komorach gazowych Pilecki zapisał:

Specjalnie jednak bolało nas, gdy w ogromnych stosach ubrań i rzeczy, należących do zagazowanych, znajdowaliśmy wśród małych buciczków i wózków dziecinnych różańce i książeczki do nabożeństwa w języku polskim. W potwornej tej rzezi zginęła, między innymi, przewieziona tu ludność kilku wiosek lubelskich. Prócz tego w tymże czasie w obozie naszym i w filiach zabito w różny sposób 11400 jeńców wojennych - bolszewików. [...]

Gazowanie zdrowych ludzi większe wrażenie zrobiło tylko po raz pierwszy. W parę miesięcy po rozpoczęciu wojny z bolszewikami władze lagru dostały kilkuset pierwszych jeńców, z których około siedmiuset, w obecności jakiejś komisji, wpakowali do jednej sali w bloku 11 (komory gazowe nie były jeszcze gotowe do użytku), stłoczyli ich tak, że stać nawet nie było miejsca, uszczelniono całą salę i w obecności świty w maskach gazowych - zagazowano ${ }^{62}$.

${ }^{59}$ Przytoczone przez Witolda Pileckiego liczby zamordowanych więźniów są znacznie zawyżone, skoro według ustaleń Franciszka Pipera w KL Auschwitz zginęło około 1,3 mln więźniów, w tym 1,1 mln pochodzenia żydowskiego (zob. idem, Ilu ludzi zginęło w KL Auschwitz. Liczba ofiar w świetle źródeł i badań, Oświęcim: Wydawnictwo Państwowego Muzeum, 1992).

${ }^{60}$ Do transportów z marca 1943 r. Pilecki nawiązał również w dalszej części raportu: „W marcu 1943 r. przywieziono do Brzezinki całe rodziny Cyganów i założono dla nich specjalny obóz. Potem część mężczyzn Cyganów przywieziono do nas. Razem z Holendrami, Norwegami, Francuzami, Żydami, Niemcami, Jugosłowianami, Grekami, Rosjanami, Ukraińcami, Belgami, Bułgarami i Rumunami tworzyliśmy istną wieżę Babel” (APMA-B, Wspomnienia, t. 183, Witold Pilecki [„Raport W”], k. 60).

${ }^{61}$ Ibidem, k. 49, 56, 63.

${ }^{62}$ Ibidem, k. 49, 57. 
W raporcie można również odnaleźć jeszcze trzy bardziej szczegółowe wzmianki wskazujące na eksterminację Żydów w obozie:

[...] Podobnie jak w Katyniu początkowo ciała zabitych (zagazowanych) grzebano $w$ Brzezince $w$ wielkich rowach, przy których pracowało specjalne „Komando”, złożone wyłącznie z Żydów, którzy żyli zaledwie dwa tygodnie, a następnie byli zagazowywani. [...]

Szczególnie cieszyły esesmanów paczki czeskie, gdyż prócz ciasta, cukru zawsze zawierały wina, pomarańcze, cytryny. Wina były konfiskowane urzędowo - lecz Czesi lub Żydzi francuscy, otrzymujący również bogate paczki, przeważnie już nie żyli - więc całe paczki szły dla esesmanów.

Od czasu do czasu w bloku zjawiali się wieczorem esesmani. Zbierali Żydów i kazali im pisać listy do domów z sakramentalnym: „Jestem zdrów i dobrze mi się powodzi". Listy te sprowadzały nowe partie Żydów, którzy na wiadomość o tym, że ich współwyznawcom tak się dobrze powodzi, chętniej zgłaszali się „na roboty do Niemiec”, oraz nowe paczki dla esesmanów, gdyż autorzy listów przez ten czas byli wykańczani ${ }^{63}$.

W odniesieniu do „Raportu W” należy również zwrócić uwagę na jeszcze jeden aspekt. W powszechnej świadomości określany jest on mianem pierwszego raportu o Holokauście. Taką informację zawiera obecnie najpopularniejsze źródło wiedzy - Wikipedia, którą pod względem merytorycznym przyrównuje się do Encyclopedia Britannica ${ }^{64}$. Jak wspomniałam, raport rzeczywiście poruszał kilka kwestii dotyczących położenia Żydów w KL Auschwitz, lecz przecież nie na nich się koncentrował. Raporty o sytuacji ludności żydowskiej w okupowanym kraju były tworzone od 1940 r. i wraz z eskalacją polityki antyżydowskiej ich liczba wzrastała ${ }^{65}$.

Według intencji Pileckiego, głównym celem „Raportu W” oraz jego osobistej interwencji w KG AK miało być uzyskanie zgody na zorganizowanie akcji zmierzającej do wyzwolenia więźniów Auschwitz. Zastosowane zabiegi nie wywołały jednak pożądanej reakcji. KG AK nie poparła planu przedstawionego przez Pileckiego, argumentując swoją odmowę m.in. bezbronnością obozowej konspiracji, która przejawiała się brakiem podstawowych środków do walki przy licznej i dobrze wyposażonej załodze SS, oraz zbyt dużym wycieńczeniem większości więźniów, co uniemożliwiłoby im ucieczkę. Problemem byłoby również przetransportowanie, zapewnienie podstawowej pomocy medycznej, a przede wszystkim ulokowanie $\mathrm{w}$ jakimś bezpiecznym miejscu tylu tysięcy więźniów. Te wszystkie środki, niezbędne do przygotowania takiej akcji, stanowiły dla Armii Krajowej towar deficytowy. Ponadto posiadane wyposażenie przeznaczano

${ }^{63}$ Ibidem, k. 57, 62.

${ }^{64}$ Zob. hasło „Raporty Pileckiego”, http://pl.wikipedia.org/wiki/Raporty_Pileckiego (dostęp 15 IV 2014 r.). Te same informacje znajdują się w anglojęzycznej edycji Wikipedii.

${ }^{65}$ Zob. Ten jest z ojczyzny mojej. Polacy z pomoca Żydom 1939-1945, oprac. Władysław Bartoszewski, Zofia Lewinówna, Kraków: Znak, 2013. 
przede wszystkim do działań wywiadowczych, sabotażowo-dywersyjnych i odwetowych. Nawet i te akcje były często odgórnymi rozkazami wstrzymywane $\mathrm{z}$ obawy przed eskalacją hitlerowskiej zemsty na narodzie polskim. Dowództwo uznało również, że z powodu ryzyka nie należy narażać bezcennych zasobów ludzkich i materiałów, które gromadzono na potrzeby ewentualnego powstania przeciwko Niemcom.

Po ucieczce $\mathrm{z}$ obozu Pilecki pod przybranym nazwiskiem Roman Jezierski zaangażował się w działalność Kedywu KG AK. Wszedł w skład nowo powstałej konspiracyjnej organizacji „NIE”. Następnie już w stopniu rotmistrza walczył w powstaniu warszawskim. Po jego upadku został wzięty do niewoli niemieckiej. Wyzwolenia doczekał w oflagu Murnau na terenie Bawarii. W lipcu $1945 \mathrm{r}$. dołączył do stacjonującego we Włoszech 2 Korpusu Polskich Sił Zbrojnych. Do Warszawy powrócił już w grudniu z misją prowadzenia działalności wywiadowczej dla 2 Korpusu. W związku z rozwiązaniem „NIE” Pilecki przystąpił do odtwarzania swojej sieci kontaktów, opierając się na byłych członkach TAP i ZOW. W tym samym czasie władze komunistyczne prowadziły akcje mające na celu rozbicie polskiego podziemia. Witold Pilecki został aresztowany 8 maja $1947 \mathrm{r}$. W wyniku wyroku sądu skazano go na karę śmierci. Nie pomogły prośby do prezydenta Bolesława Bieruta o ułaskawienie żołnierza dwóch wojen światowych i organizatora obozowego ruchu oporu. Witold Pilecki został zamordowany strzałem w tył głowy 25 maja $1948 \mathrm{r}$.

W dalszym ciągu wiele kwestii związanych z jego zatrzymaniem i śmiercią wymaga wyjaśnienia i rozstrzygnięcia, zwłaszcza że dopiero upadek ustroju komunistycznego uwolnił narrację historyczną od ograniczeń cenzury. Zarazem jednak nie zniknęły trudności w pisaniu o niektórych kwestiach, które mogłyby naruszyć bohaterską legendę Pileckiego ${ }^{66}$.

Niniejszy artykuł nie pretenduje do wyczerpania zagadnień dotyczących niewyjaśnionych jeszcze spraw związanych z Witoldem Pileckim, pozostawiając to zadanie jego kolejnym biografom. Wśród realizowanych od lat dziewięćdziesiątych inicjatyw mających upamiętnić Pileckiego stawia sobie za cel jedynie zwrócenie uwagi na konieczność skorygowania i uzupełnienia biografii Pileckiego przez dokładne i ostrożne przestudiowanie wszystkich dostępnych źródeł. Pozwoli to uniknąć powielania w powszechnym obiegu błędów merytorycznych

\footnotetext{
${ }^{66} \mathrm{O}$ podważenie legendy Pileckiego został nie tak dawno oskarżony prof. Andrzej Romanowski (literaturoznawca, pracownik Wydziału Polonistyki UJ, publicysta). W tekście Tajemnica Witolda Pileckiego („Polityka” 2013, nr 20) odwołał się do wspominanego przeze mnie wydanego przez IPN w 2008 r. albumu autorstwa Jacka Pawłowicza (Rotmistrz Witold Pilecki [1901-1948]). Szczególną uwagę Romanowski zwrócił na protokoły przesłuchań Witolda Pileckiego. Z treści zeznań wynika, że Pilecki wyjawił funkcjonariuszom UB nazwiska swoich konspiracyjnych współpracowników. Fakt ten zdaniem Romanowskiego kłóci się z utrzymanymi w „tonie hagiograficznym” tekstami inaugurującymi publikację IPN. Artykuł wywołał liczne polemiki (rzadko merytoryczne), podejmowane zwłaszcza przez prawicowe media, oraz falę oskarżeń Romanowskiego o „haniebny atak” na pamięć o rtm. Pileckim.
} 
i stosowania nieprecyzyjnych określeń, a przede wszystkim niepotrzebnej mitologizacji, której bez wątpienia bohaterska postać rotmistrza Witolda Pileckiego po prostu nie potrzebuje.

\title{
Słowa kluczowe
}

Witold Pilecki, rotmistrz Pilecki, ochotnik do Auschwitz, raport Pileckiego, raport „W”

\begin{abstract}
This article is an attempt to analyse the historical memory of Witold Pilecki functioning in the reference literature and collective consciousness. The author concentrates on their idealising and simplistic elements, which lead to mythologization of Pilecki, and asks about the genesis and purpose of creation of myths about the Captain. Basing on an analysis of the sources, Cuber-Strutyńska questions the legitimacy of the two popular expressions used with regard to Pilecki, that is, "volunteer to Auschwitz" and "the author of the first report about the Holocaust." In this way the author points out the necessity to correct and supplement Pilecki's biography by means of a careful and cautious analysis of all the available sources.
\end{abstract}

\section{Key words}

Witold Pilecki, Captain Pilecki, volunteer to Auschwitz, Pilecki's report, Report “W" 